\title{
Museumssociologi
}

\section{En slags genlæsning af især Dorte Skot-Hansens Museerne i den danske oplevelsesøkonomi (2008)}

\author{
Hans Dam Christensen
}

Blandt Dorte Skot-Hansens publikationer findes mange titler, som eksplicit handler om folkebibiblioteker, kulturpolitik, kulturformidling og kulturplanlægning anskuet i en kultursociologs optik. På en lille fin hylde i forfatterskabet findes desuden en håndfuld publikationer, der mere specifikt handler om museer. Især bogen Museerne i den danske oplevelsesøkonomi: Når oplysning bliver til en oplevelse (2008) skal bemærkes, og nævnes i sammenhæng hermed bør også forskningsartiklerne "Digital formidling i danske museer: Udfordringer fra oplevelsessamfund og oplevelsesøkonomi" (2009) og "Danske museer som børs eller katedral: Udfordringer fra oplevelsessamfund og oplevelsesøkonomi" (2009). Som det fælles udgivelsesår og den identiske undertitel antyder, er begge delvist affødt af førstnævnte bog; den vender vi tilbage til.

I en meget mindre skala findes desuden klassikeranmeldelsen, "Pierre Bourdieu, Alain Darbel and Dominique Aschnapper, The love of art: European art museums and their publics" (2010), som tydeligt demonstrerer anmelderens faible for Bourdieu. På grænsen mellem museer og noget andet kan nævnes forskningsartiklen "Fransk kultur i undtagelsestilstand - franske kunst- og kulturarenaer i en digital æra" (2013), der blandt andet vender tilbage til Centre Pompidou i Paris, som sammen med Centre

Hans Dam Christensen, professor, vicedirektør Det Informationsvidenskabelige Akademi, Københavns Universitet, hansdam@hum.ku.dk
André Malraux i Rouen også var i fokus i den meget mindre artikel, "To franske kulturhuse- et impressionistisk studie", tilbage fra 1979 (Skot-Hansen, 1979).

I den nyere artikel inddrages blandt andet Musée d'Orsay og Musée du quai Branly i en analyse, som bemærker, at Centre Pompidou fortsat tiltrækker mange besøgende, men nok ikke helt længere opfylder det oprindelige formål om at fungere som "en kulturfabrik for kreativitet" (Skot-Hansen, 2013, s. 2013). Artiklen afslutter kort efter med at konkludere, at der "... er brug for en kulturpolitik 2.0 - eller 3.0 - der ikke kun ser digitaliseringen som et middel til kulturformidling, men som et grundvilkår, der fundamentalt ændrer vores måder at kommunikere indbyrdes og at konstruere verden omkring os" (Skot-Hansen, 2013, s. 2013.).

I virkeligheden kan man ikke afgrænse Dorte SkotHansens tekster om museer på denne måde. Museerne dukker op mange steder. I bogen Byen som scene: Kultur- og byplanloegning i oplevelsessamfundet fra 2007 finder man eksempelvis analyser af det new york'ske Guggenheim Museums strategi for inddragelse af yngre samlere og potentielle fremtidige mæcener såvel som New Zealands Te Papa Museum, der formår at forene interaktive digitale medier og oplevelse, uden at kvaliteten som vidensformidler går tabt (Skot-Hansen, 2007, s. 30-33; bogen blev genoptrykt i 2014 i en let udvidet version).

Vender man tilbage til de hjemlige breddegrader, ja, så får især Holstebro Kunstmuseum, men også 
samme bys kulturhistoriske museum, med fuld rimelighed plads i bogen Holstebro $i$ verden - Verden $i$ Holstebro: Kulturpolitik og-debat fra tresserne til $i$ dag (1998). Kunstmuseet repræsenterer på flere måder den moderne kunsts indtog i byen med fokus på blandt andet få samtidige danske navne med mange værker og flere internationalt anerkendte kunstnere repræsenteret med grafiske værker. Det kulturhistoriske museum bliver særligt interessant på grund af dets "Birn Wing". Det er den del af museet, som blev finansieret af Vald. Birns Jernstøberi og Maskinfabrik A/S i 1996 med forpligtelse til at fortælle ikke blot jernets kulturhistorie, men desuden mere specifikt firmaets historie med eksempler fra også den nyeste produktion. Da byggeriet var under opførelse ved bogens udgivelse, lader Dorte Skot-Hansen overskriften "Sales-room eller museumsfløj" stå åben, men problemstillingen interesserer hende, fordi relationen mellem økonomi, oplysning og oplevelse skaber spændinger (Skot-Hansen, 1998, s. 188-189).

Dorte Skot-Hansens mest omfattende værk om museumsfeltet er imidlertid de cirka 145 sider i ovennævnte Museerne i den danske oplevelsesøkonomi: Når oplysning bliver til en oplevelse (2008). Det er en rapport med fire hovedkapitler, "Museumsfeltet i forandring", "Oplevelse som omdrejningspunkt", "Digital formidling - innovation og kreative alliancer" samt "Museer og kulturarv i by- og regionsudviklingen". Den blev udgivet i regi af Imagine .. Creative Industries Research, et forskningscenter på CBS, der udforsker organiseringen af kreativitet i virksomheder, projekter og transnationale netværk. Andre rapporter i denne serie, der i øvrigt udkom samtidig, belyser idræt og sport, events, film, software games og mode i den danske oplevelsesøkonomi. Rapporterne var afledt af det treårige forskningsprojekt, Kunst, Kompetence og Konkurrenceevne $i$ den Danske Oplevelsesøkonomi, som Tuborgfondet bevilgede over 6 mio. kroner til tilbage i 2005 i anledning af Fondets 75 års jubilæum. Som det første af sin slags skulle det kortlægge den danske oplevelsesøkonomi, undersøge barrierer for vækst og udvikle nye ledelsesværktøjer samt udføres i tæt samarbejde med erhvervslivet.

Det er interessant, at museumsfeltet blev optaget $\mathrm{i}$ selskab med fx idræt, film og computerspil, fordi undersøgelsen Danskernes kultur- og fritidsaktiviteter 2004 - med udviklingslinjer tilbage til 1964 (Bille et al., 2005) kort inden havde vist, at computerspil og internet, biografbesøg og film samt sport og motion var noget, danskerne i stigende grad interesserede sig for, mens besøgstallet på kunstmuseerne var stagneret og direkte faldende på kultur- og naturhistoriske museer. Siden er kurverne for museumsbesøg som bekendt vendt, så på den lange bane viste inddragelsen af museer i det større forskningsprojekt sig at være velvalgt.

Museernes inddragelse er også interessant, fordi Dorte Skot-Hansen ikke uden videre kaster dem ned i oplevelsesøkonomiens malstrøm. Den overordnede konklusion er nemlig, at museer ikke skal vurderes efter deres bidrag til samfundsøkonomien, men efter deres kunstneriske, kulturelle og kulturpolitiske dagsordener (Skot-Hansen, 2008, s. 130). En lidt mindre pointe er dog samtidig, at museer skal skærpe opmærksomheden på de kommercielle sider af driften og udvikle deres "oplevelsespotentialer" det skal ske med refleksion omkring, hvor langt man kan bevæge sig uden at miste den kulturpolitiske legitimitet. Oplevelsesøkonomisk tænkning kan hjælpe på vej: "Museerne skal lære at navigere i et helt nyt videns- og oplevelsessamfund, så museernes basale opgaver omkring indsamling, bevaring, forskning og formidling integreres i gode oplevelser" (131). For ikke at ende som følelsesfabrik kræver det ifølge forfatteren blandt andet et differentieret oplevelsesbegreb (83). En vellykket navigation, som desuden involverer digital formidling, kan gøre museerne "... til drivere i udviklingen af innovative it-baserede formidlingsformer i kreative alliancer med andre medspillere, og de kan fungere som vækstdynamoer i den lokale og regionale udvikling" (131).

Sidstnævnte punkt om betydningen for lokal og regional udvikling indskriver sig i en samtidig diskussion, hvor strategiske satsninger på kulturarven i form af eksempelvis "kulturarvskommuner" ifølge forfatteren er "... et led i den instrumentalisering af kulturen, der har været et generelt træk ved kulturpolitikken i både Danmark og internationalt siden 1990'erne" (125). I stedet for blot at være en ressource i et større oplysningsprojekt er der nu tale om potentiale som regional økonomisk vækstfaktor i forbindelse med eksempelvis turisme (125).

Museernes potentiale som drivere af digital formidling i samarbejde med eksterne medspillere i førnævnte citat indskriver sig tydeligvis i det Tuborgfond-støttede forskningsprojekts fokus på udvikling 
af værdipotentialer i oplevelsesøkonomien og herigennem, trods alt, tænkelige bidrag til samfundsøkonomien. Det, som forfatteren påpeger, er netop muligheden for at koble kommercielle virksomheder til museet som oplevelsesinstitution ved at initiere samarbejder mellem private og offentlige partnere omkring udvikling af digitale formidlingsløsninger. I forlængelse af balancen mellem oplysning og oplevelse mener forfatteren, at museerne generelt godt kan gå videre end de på dette tidspunkt har gjort, uden at kvaliteten af vidensformidlingen tabes igennem et sådan samarbejde. Hun er dog skeptisk over for de økonomiske vækstmuligheder på den korte bane. Der findes et potentiale i det danske miljø for udvikling af kreative digitale formidlingsprojekter, "... men der er langt igen, før vi er på forkant på området ..." (102).

Uden at gå i yderligere detaljer er Museerne $i$ den danske oplevelsesøkonomi en vigtig kortlægning af aktiviteter og initiativer med henblik på oplevelsesøkonomiens potentialer i første halvdel af 00 'erne. Det indsamlede materiale, som ligger til grund for bogens fire hovedkapitler, afspejler som sådan en specifik historisk situation. Eksempelvis er museumsloven siden blevet revideret, nye museumsdirektører er kommet til, museer er blevet fusioneret, på det seneste er den fri adgang til Nationalmuseet og Statens Museum for Kunst igen ophævet, og, ikke mindst, de digitale teknologier og medier har udviklet sig siden mobilt tv, Web 2.0., p2p og Myspace (87).

I en 2016-optik synes bogen derfor af indlysende grunde forældet på nogle punkter. På den anden side har den netop fået ny styrke i sin kortlægning, fordi den nu opsummerer, hvad der fandtes af initiativer. Forfatteren beskriver nemlig et felt, der paradoksalt nok er præget af amnesi. Overlevende projekter huskes - og dem er der heldigvis også en del af i denne kortlægning - men projekter, der eksempelvis ikke var tilstrækkeligt forankrede i den specifikke organisation eller af teknologiske årsager blev forældede, er oftest forsvundet ud af erindringen, hvorved vigtige erfaringer kan være gået tabt for efterfølgende projekter.

Derudover, og ikke mindst, er netop de strategiske overvejelser omkring hvilke veje, museerne kunne tage tilbage i 2008, interessante, især fordi den digitale udvikling forventeligt har sat sig dybe spor i nye formidlingsformer. På samme måde har den brugerinddragelse, der ligger i oplevelsesdimensionerne, sat sine tydelige spor. Det er blandt andet sket med begrebet deltagelseskultur, som for museernes vedkommende spidsformuleres et par år efter med ikke mindst Nina Simons The Participatory Museum (2010), der tillige peger på brugerdeltagende aktiviteter uden brug af digitale medier.

Måske er det alligevel ikke så underligt, at museerne inddrages i en undersøgelse af den danske oplevelsesøkonomi anno 2008. I hvert fald er der i perioden generelt fokus på både muligheder for udvikling af brugerinddragende museumsformidling og forskellige sider af kulturens værdipotentialer. På den ene side er der således fokus på især museerne som formidlingsinstitutioner med publikationer såsom Kulturministeriets Udredning om museernes formidling (Udredning, 2006) og Kulturarvsstyrelsens Digital museumsformidling - $i$ brugerperspektiv, (Digital museumsformidling, 2009) samt, med inddragelse af også andre kulturinstitutioner, Kulturministeriets Reach Out (Reach Out, 2008).

På den anden side kan der også peges på udgivelser som det daværende Økonomi- og Erhvervsministeriums Danmark $i$ kultur- og oplevelsesøkonomien - 5 nye skridt på vejen (Danmark i kultur- og oplevelsesøkonomien, 2003), Rambøll Managements Oplevelsesøkonomi i Hovedstadsregionen (Oplevelsesøkonomi, 2005) samt Vækstfondens Oplevelsesindustrien - perspektiver for ivcerkscetteri og venturekapital (Oplevelsesindustrien, 2007), der på forskellig måde peger på potentielle alliancer mellem kulturinstitutioner og kommercielle aktører omkring oplevelse. Måske kan man i denne sammenhæng trods alt også nævne Lise Lycks Museer - Hvornår og hvordan? (2010). Den lidt tøvende indstilling skyldes, at værket nok er i stand til at henvise til en lille internettekst om museumsdefinitioner af denne artikels forfatter, men af uvisse grunde helt undlader referencer til bogen Museerne i den danske oplevelsesøkonomi, selv om Lyck har fokus på oplevelsesøkonomi og samspil mellem kultur- og erhvervspolitik. Den overordnede pointe er dog, at der er en generel samfundsinteresse for museerne, der på dette tidspunkt rækker ud over universiteternes museumsstudier.

I sidste ende kan inddragelsen af museer i en undersøgelse af dansk oplevelsesøkonomi også ses i et hi- 
storisk lys. Med henblik på at synliggøre og forbedre museernes formidling stillede man tilbage i $1969 \mathrm{i}$ det daværende kulturministeriums En kulturpolitiske redegørelse. Betcenkning 517 eksempelvis forsigtige spørgsmål som: "Vil det være rimeligt, at museet får midler til rådighed til løbende annoncering i dagblade og ugeblade?" Og: "På privat initiativ foretages store undersøgelser om folks forbrugsvaner. Bør det moderne publikums ønsker og krav til et museumsbesøg, herunder åbningstider, nærmere udforskes?" (En kulturpolitisk redegørelse, s. 158). Cirka fyrre år efter var der på begge disse områder sket store forandringer, som havde bidraget til både professionalisering, øget interesse for brugerinddragelse og kulturøkonomisk værdiskabelse. Denne voldsomme udvikling gjorde formentlig også museumsfeltet til interessant studieobjekt i en kortlægning af den danske oplevelsesøkonomi

Skal Dorte Skot-Hansens indsats på museumsfeltet opsummeres ganske kort, handler den især om balancen mellem oplysning og oplevelse - begrebsparret går igen i mange af publikationerne i hendes forfatterskab. Der er ingen tvivl om, at der i forfatterens optik er plads til mere oplevelse, uden at det vil gå ud over i dette tilfælde museernes troværdighed som formidlere af viden. Brugerne skal inddrages, og digitale medier kan hjælpe godt på vej. I Museerne i den danske oplevelsesøkonomi tales der ligefrem om et dannelsesprojekt, hvor den "... klassiske modsætning mellem oplevelse og oplysning, fornuft og følelse ophæves i en ny museumsforståelse. Den klassiske modsætning mellem oplevelse og vidensformidling er ophævet, fordi en ny internetbaseret kultur har sat nye normer for videnstilegnelse og oplevelser og ændret forholdet mellem dem. (SkotHansen, 2008, s. 130)

Selv om der er tale om et tilfældigt sammentræf, må det derfor glæde et kombineret forsker- og formidlerhjerte som Dorte Skot-Hansens, at et i dansk sammenhæng meget stort forskningprojekt om museumsformidling, Vores Museer, søsættes i skrivende stund. Som overordnet tese mener projektet netop, at museer historisk set skabes og udvikles i et spændingsfelt mellem en opfattelse af museet som middel for befolkningens oplysning og som mål for besøgendes oplevelser. Det er dette spændingsfelt, som i særlig grad kommer til syne som de dilemmaer, nutidige formidlingspraksisser forsøger at navigere mellem. Projektet er for en stor del støttet af to pri- vate fonde, Veluxfonden og Nordeafonden, der har interesser i både forskning og gode oplevelser, og flere af projekterne bærer for Dorte Skot-Hansen formentlig klangfulde arbejdstitler som eksempelvis "Digitale deltagere som ressourcer for museet", "Museet som (virtuelt) oplevelsesrum: fragmentering eller synergi?", "Brugerdeltagelse som social katalysator", "Design og evaluering af interaktive digitale oplevelser som middel til læring" samt "Virker det? En evidensbaseret analyse af digital museumsformidling i Danmark siden 1990" (Dansk museumsformidling, 2015)

Der er sket rigtigt meget på det kulturpolitiske felt siden de forsigtige spørgsmål om annoncering og brugerundersøgelser i førnævnte Betcenkning 517. Den udkom blot fem år, før Dorte Skot-Hansen blev fastansat på den daværende Danmarks Biblioteksskole som først underviser og siden lektor i kulturformidling og bibliotekssociologi; herigennem blev hun selv en væsentlig aktør i forandringerne.

\section{Referencer}

Bille, T, Fridberg, T, Storgaard, S \& Wulff, E (2005). Danskernes kultur- og fritidsaktiviteter 2004 - med udviklingslinjer tilbage til 1964. København: Kulturministeriet .

Danmark i kultur- og oplevelsesøkonomien - 5 nye skridt på vejen (2003). København: Økonomi- og Erhvervsministeriet.

Dansk museumsformidling: historik, design og evaluering (2015). Ansøgning til Veluxfonden og Nordeafonden.

\section{Digital museumsformidling - $i$ brugerperspektiv (2009). København: Kulturarvsstyrelsen.}

En kulturpolitisk redegørelse. Betcenkning 517 (1969). København: Ministeriet for kulturelle anliggender.

Lyck, L (2010). Museer: Hvornår og hvordan? København: Center for Tourism and Culture Management.

Oplevelsesindustrien: perspektiver for ivarkscetteri og venturekapital (2007). København: Vækstfonden. 
Oplevelsesøkonomi i Hovedstadsregionen (2005). København: Rambøll Management.

Reach Out (2008). København: Kulturministeriet.

Simon, N (2010). The Participatory Museum. Museum 2.0.

Skot-Hansen, D (1979). To franske kulturhuse - et impressionistisk studie. Bibliotek 70, Bibliotekarforbundets blad, 10 (14), s. 388-390.

Skot-Hansen, D (1998). Holstebro i verden - Verden i Holstebro: kulturpolitik og -debat fra tresserne til $i$ dag. Aarhus: Klim.

Skot-Hansen, D (2007). Byen som scene: kultur- og byplanlcegning i oplevelsessamfundet. København: Bibliotekarforbundet.

Skot-Hansen, D (2008). Museerne i den danske oplevelsesøkonomi: når oplysning bliver til oplevelse. København: Samfundslitteratur.
Skot-Hansen, D (2009). Danske museer som børs eller katedral: udfordringer fra oplevelsessamfund og oplevelsesøkonomi. Nordisk Kulturpolitisk Tidskrift, 12 (1), 140-167.

Skot-Hansen, D (2009). Digital formidling i danske museer: Udfordringer fra oplevelsessamfund og oplevelsesøkonomi. I: Lund, ND, Andersen, J, Dam Christensen, H, Skouvig, L \& Johannsen, CG (Eds.), Digital formidling af kulturarv: fra samling til sampling (43-64). København: Multivers.

Skot-Hansen, D (2010). Pierre Bourdieu, Alain Darbel and Dominique Aschnapper, The love of art:

European art museums and their publics. International Journal of Cultural Policy, 16 (1), 76-77.

Skot-Hansen, D (2013). Fransk kultur i undtagelsestilstand - franske kunst- og kulturarenaer i en digital æra. Nordisk Kulturpolitisk Tidskrift 16 (2), 201-216.

Udredning om museernes formidling (2006). København: Kulturministeriet. 